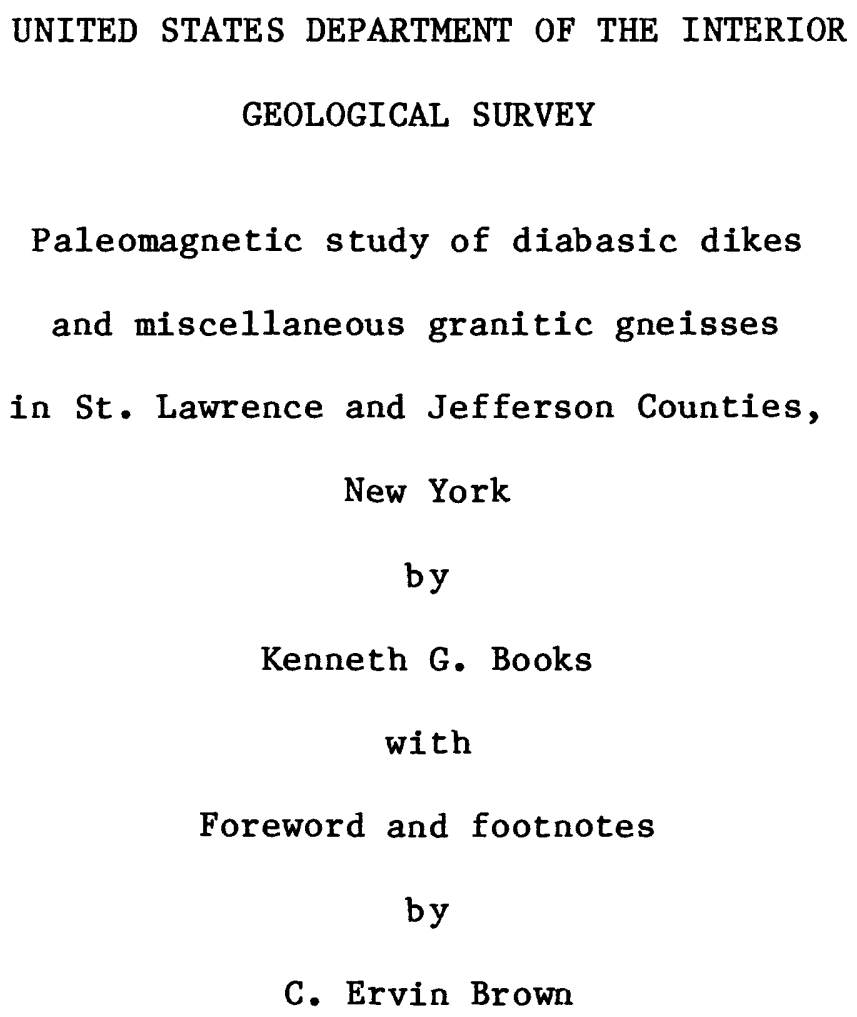

C. Ervin Brown

Open-File Report 83-226

This report is preliminary and has not been reviewed for conformity with U.S. Geological Survey editorial standards and stratigraphic nomenclature. 
Table of Contents

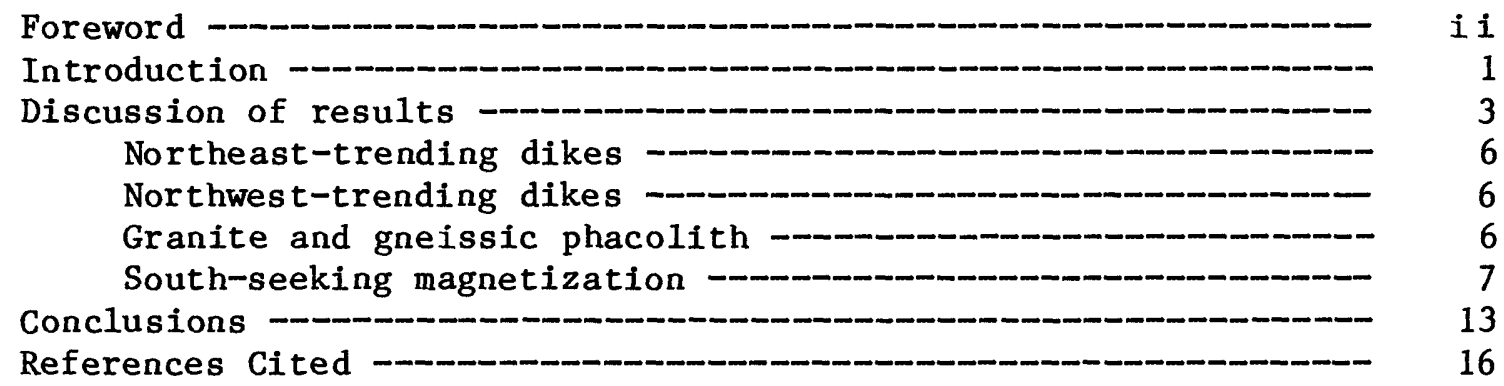

\section{Illustrations}

Figure 1. Paleomagnetic sample collection sites. Asterisk indicates samples having magnetic directions too scattered to use. -

2a. Mean of site-mean directions of magnetization for northeast-trending dikes.--- 4

$2 b$. Mean of site-mean directions of magnetization for northwest-trending dikes. - -

3a. Site-mean directions of magnetization for A.C. (alternating current) partial demagnetization steps of site EB-2. NRM is the direction of natural remanent magnetization.

3b. Site-mean directions of magnetization for A.C. (alternating current) partial demagnetization steps of site EB-101. NRM is the direction of natural remanent magnetization.

3c. Site-mean directions of magnetization for A.C. (alternating current) partial demagnetization steps of site EB-104. NRM is direction of natural remanent magnetization.

3d. Site-mean directions of magnetization for A.C. (alternating current) partial demagnetization steps of site EB-202. NRM is direction of natural remanent magnetization.

4. Mean of site-mean directions of magnetization for the south-seeking component of magnetization at the various sites. -

Tables

Table 1. Summary of results. 
Foreword

by

C. Ervin Brown

\section{Geologic situation}

Fine-grained mafic dikes that are generally vertical, narrow, and undeformed are exposed in roadcuts near Gouverneur, N.Y. and others were noted by geologists at several places in the vicinity. A particularly notable group of dikes are on Grindstone Island in the St. Lawrence River near Clayton, N.Y. and many more are nearby in Ontario. These have been mapped and described by various workers (Cushing and others, 1910; Smyth, 1894), but those in New York have aroused only slight geologic notice.

In the late 1960's I mapped a dike that is $12-18 \mathrm{~m}$ (40-60 feet) wide throughout its mapped extent of more than $16 \mathrm{~km}$ ( $10 \mathrm{miles}$ ) in the Beaver Creek drainage basin of St. Lawrence County. Parallel but narrower dikes within about $3 \mathrm{~km}$ ( 2 miles) were also mapped.

The dikes show chilled borders, have amygdaloids, are undeformed, and have undergone some saussuritization. The large dike has diabasic texture but is an alkalic, sub silicic, olivine and analcite-bearing rock (Brown, 1975). Dikes on both sides of the St. Lawrence intrude all rocks of Precambrian age in the Lowlands. At no place do they intrude the patchy remnants of overlying sedimentary rocks of Upper Cambrian age. In fact, the dikes show deep weathering where exposed close to the pre Upper Cambrian unconformity. They certainly appear to have been truncated by that erosional event.

Most of the dikes in the area including those near Beaver Creek trend to the northeast. A few dikes to the west and southwest trend to the north or northwest and are different petrologically in that they are not undersaturated and are less altered. Similar trending dikes also occur nearby in Ontario.

\section{Age problem}

$\mathrm{K}-\mathrm{Ar}$ dates on pyroxene and feldspar on the large northeast-trending dike are $405 \pm 11 \mathrm{~m} \cdot \mathrm{y}_{\bullet}$ and $440 \pm 10 \mathrm{~m} . \mathrm{y} \cdot$, respectively (Brown, 1975). Unfortunately, these dates do not agree within the limits of the analytical uncertainty, but the pyroxene date does agree with two $\mathrm{K}-\mathrm{Ar}$ wholerock ages of $407 \pm 23 \mathrm{~m} \cdot \mathrm{y}$. and $411 \pm 23 \mathrm{~m} \cdot \mathrm{y}$. reported on a northwesttrending dike nearby in Ontario (Park and Irving, 1972). These dates are clearly not compatible with the Pre-Upper Cambrian age required by the field relations. Ages in the $600-800 \mathrm{~m} . \mathrm{y}$. range for other dikes in Ontario reported by Park and Irving are probably closer to the actual time of intrusion. Because of the discrepancy between isotopic dates and field relations, a paleomagnetic study was suggested to 
determine pole positions during crystallization of the dike rock. Comparison with polar wandering curves could aid speculation on the approximate age of intrusion and enable correlation with similar data on the dikes in Ontario (Park and Irving, 1972). Also polar data could aid in determining whether dikes of different trend and composition are of separate magmatic events.

This geologic situation was the incentive for the paleomagnetic study that is the subject of this report by Kenneth G. Books prepared in 1978 before his retirement. 


\title{
Paleomagnetic study of diabasic dikes and \\ miscellaneous granitic gneisses in St. Lawrence and \\ Jefferson Counties, New York
}

by

Kenneth G. Books

Introduction

\begin{abstract}
Magnetic property measurements on samples $1 /$ from diabase dikes in St. Lawrence and Jefferson Counties, N.Y. were done in an effort to relate ages of the dikes and the Upper Cambrian Potsdam Sandstone. Sample collections were also made on a Precambrian "phacolith" and "granite intrusion"르 (fig. 1).

Previous work by Park and Irving (1972) on dikes in the Gananoque area, Ontario, Canada had shown differing paleomagnetic field directions for the north-, northeast-, and northwest-trending dikes. According to their data, radiometric measurements indicate a minimum age of $800 \mathrm{~m} . \mathrm{y}$. for northeast-trending dikes and minimum of $407 \pm 23 \mathrm{~m} . \mathrm{y} ., 411 \pm 23 \mathrm{~m} . \mathrm{y}$. , and $434 \pm 75 \mathrm{~m} . \mathrm{y}$. for northwest-trending dikes (see Foreword). An age of $675 \mathrm{~m} . \mathrm{y}$. was estimated for a north-trending dike by comparison of the magnetic pole with that of the Franklin diabase (Fahrig et al., 1971).
\end{abstract}

1/Sampling was done during brief visits to the field in 1972, 1975 and 1976. Oriented cores were collected by Books and Brown assisted by John Windolph in the spring of 1972, in 1975 with the assistance of Harold Hubbard, and on Grindstone Island by Ken Books and William Huff in the spring of 1976 . C.E.B.

2/Samples were collected from the Hyde School "phacolith" of Buddington (1929). Now believed to be a domical upwarp of metamorphosed and recrystallized ash-flow tuffs ranging from diorite to alaskite in composition (Carl and Van Diver, 1975) and representing some of the oldest rocks of the region.

The "granite intrusion" is a peneconcordant sheet of granite that invades metasediments of the Grenville Complex $4 \mathrm{~km}(2.5 \mathrm{mi})$ north of North Gouverneur, N.Y. C.E.B. 
Although relative ages of the dikes and Potsdam Sandstone could not be resolved because of poor precision for the sandstone samples, the dike, granite intrusion, and gneissic phacolith sample data are worth discussing. Magnetic property measurements on all samples were made in the U.S. Geological Survey's Magnetic Properties Laboratory in Reston, Va. All data were reduced with computer programs and are presented in terms of declination (D), measured in degrees east of geographic north, and inclination (I), measured in degrees below the horizontal. In the various figures, remanence results are plotted on the lower hemisphere of an equal-area net to permit direct comparison of directions on a single plane, regardless of polarity. Solid circles represent polarization north-seeking down and open circles represent polarization south-seeking down.

\section{Discussion of results}

The collection sites consist of five granites, one gneiss, and 24 sites on diabase dikes. Of these, one of the granite, one of the gneiss, and nine of the diabase dike sample sets l/ had their directions of magnetization too scattered to be used after partial demagnetization in AC (alternating current) fields up to 1000 oersteds. The useable data for the 15 dikes are shown in Figures $2 a$ and $2 b$.

1/The dike samples with scattered magnetic directions are from the following sites EB-6, 9, 11, 13, 14, 102, 106, 204, 209 and 210. Although not explaining the scatter of magnetization, it is interesting that these include all samples from very narrow ( $<10$ feet wide) finegrained dikes $(11,13,14,102,106)$--that are also strongly saussuritized. In addition, 9, 102, 209, and 210 are from we11-weathered rock all close vertically to the pre-Upper Cambrian unconformity and thus were exposed to oxidation at that time as well as now. These factors possibly contributed to the erratic scatter of magnetization directions. C.E.B. 


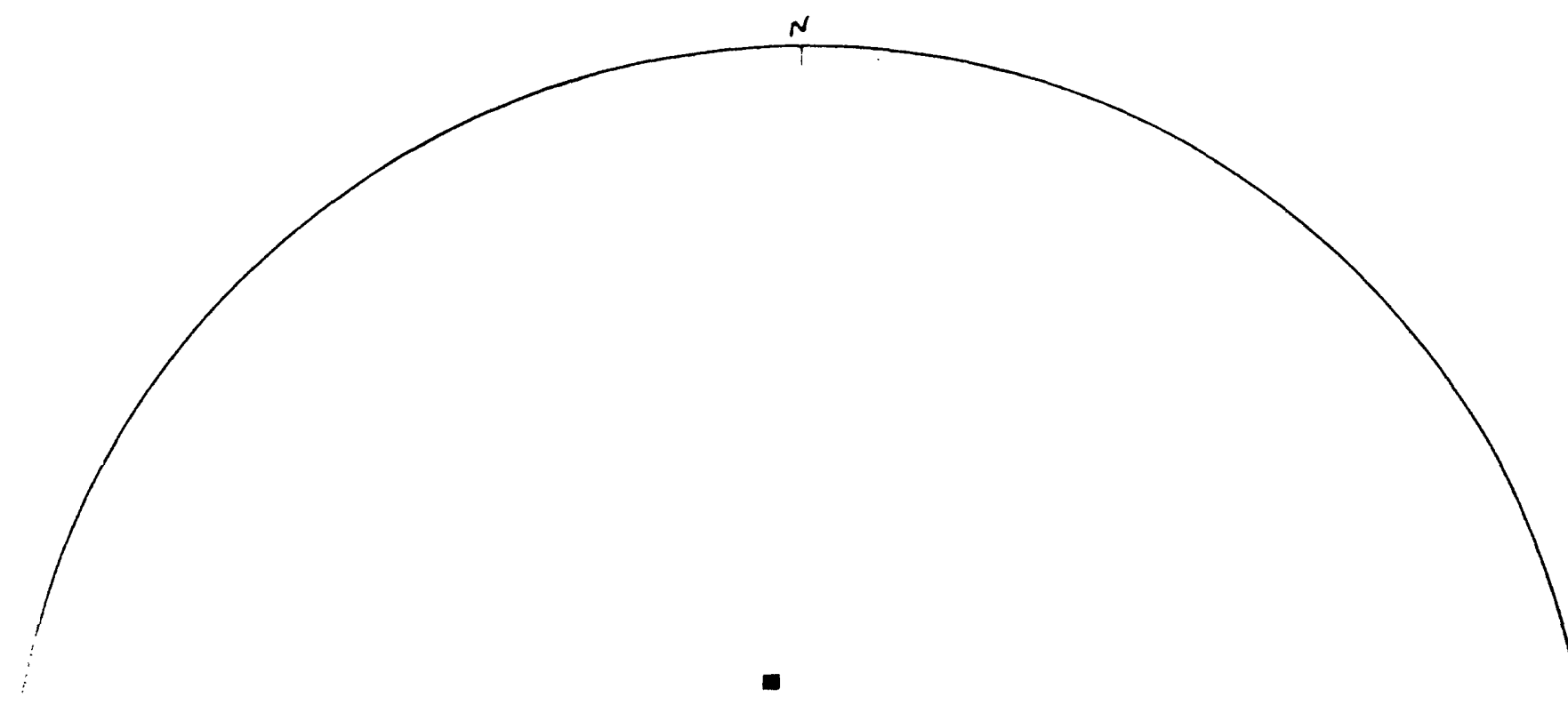

W -

t

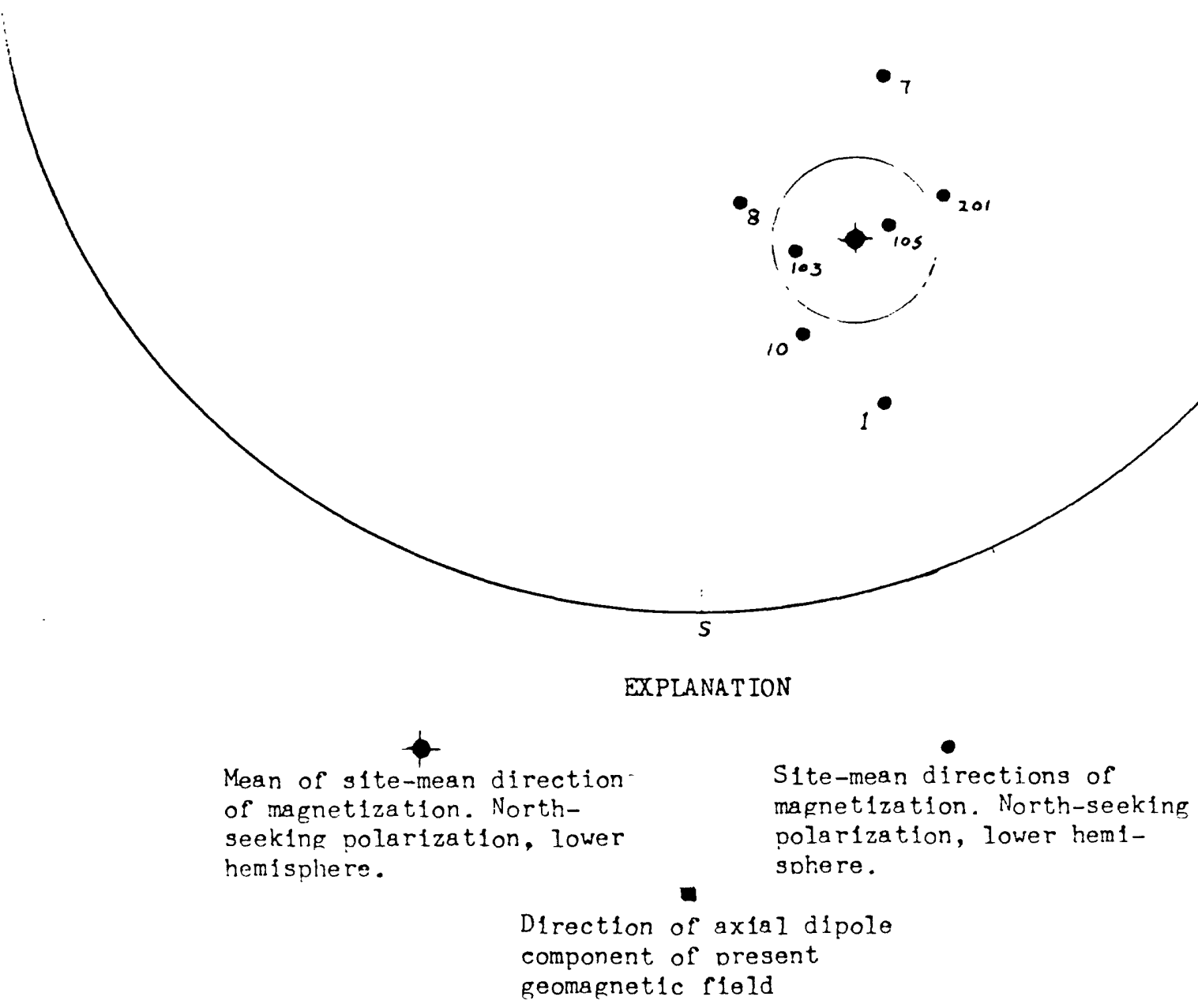

Figure 2a.--Mean of site-mean directions of magnetization for northeast-trending dikes. 


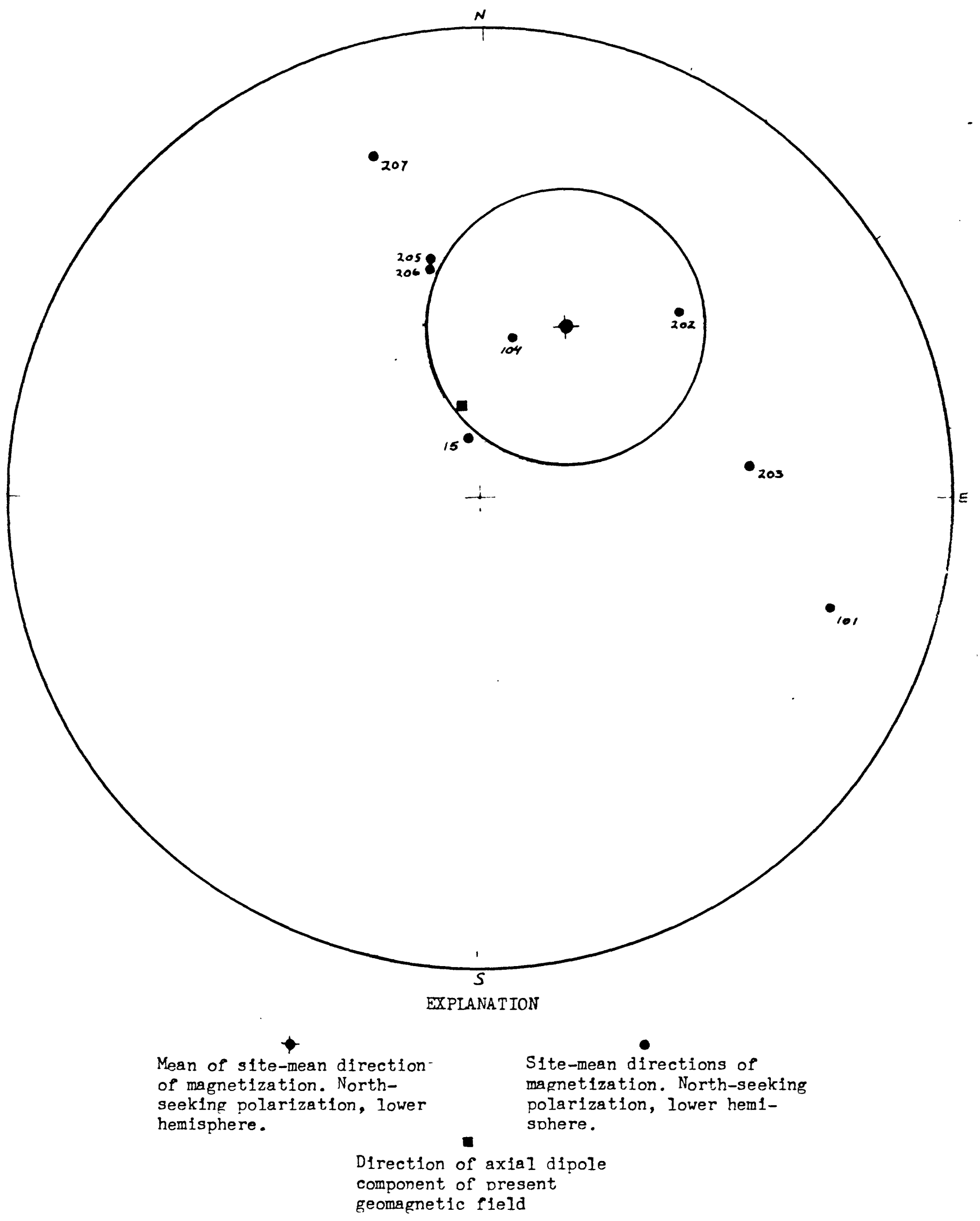

Figure 2b.--Mean of site-mean directions of magnetization for northwest-trending dikes. 
Northeast-trending dikes

These are the most common dike trends in the area of collection in St. Lawrence and Jefferson Counties. Although precision is not great, the dikes include the more closely grouped directions of magnetization, both within and between sites. Of the 13 dikes sampled, only seven had useable data, and of the seven, one was of mixed polarity and the southseeking component vanished above the 400 oersted demagnetizing field. Figure $2 a$ shows the north-seeking magnetization for these dikes grouping in the southeast quadrant of an equal-area net.1/

Northwest-trending dikes

Site magnetic directions for these dike samples, most of which are from Grindstone Island north of Clayton, N.Y., are shown in Figure $2 b$. Scatter for magnetic directions is large, both within and between sites. Of seven sites utilized, three have a mixed polarity. The north-seeking magnetization for these dikes clusters in the northeast quadrant of the equal-area net.

Granite and gneissic phacolith

Magnetic directions for four sites on a granite intrusion southeast of Hickory Lake in St. Lawrence County are somewhat scattered as are directions for one site on a gneissic "phacolith" southwest of Hickory Lake. All five sites have their magnetization initially north-seeking but quickly become south-seeking during partial AC demagnetization in fields up to 500 oersteds.

$1 /$ The seven samples from northeast-trending dikes also have the following common characteristics (see Table 1 and Figure 2a): Sample sites $\mathrm{EB}-1,8,10$, and 105 are all on the same northeast-trending dike. EB-7 is from a parallel dike 9000 feet to the northwest. EB-103 is from a wide northeast-trending dike exposed in roadcuts along Interstate route 81 about 22 miles to the southwest nearly on trend of the above dikes. EB-201 is on a large irregularly shaped dike on Grindstone Island, possibly having a northeast trend. Thus, except for possibly EB-201, they appear to form a long narrow northeast-trending belt. Unlike the samples from narrow chilled dikes that gave mixed unusable results, these are all from wide dikes, mostly more than 30 feet, that internally are well crystallized and are phaneritic with diabasic texture.

The relatively tight grouping of north-seeking poles shown on Figure $2 a$ probably is the most significant result of this study. Books has not been able to match this with Parke and Irving's data (1972) or the Logan Loop recorded from rocks in the Lake Superior region (Pesonen and Halls, 1979). If the average pole position of the NE-trending dike were south-seeking rather than north-seeking it would match closest to the pole for Sioux quartzite (Books, personal commun., 1982). C.E.B. 


\section{South-seeking magnetization}

At about half of the sites, the directions of magnetization are north-seeking down, but at five of the 15 diabase dike sites and all of the granite and gneiss sites, the magnetization is either initially partly south-seeking or becomes south-seeking as the samples are partially demagnetized. Figures 3a-3d illustrate these characteristics. Site EB2 (fig. 3a) is representative of the one gneiss and five granite sites. These have their natural remanent magnetism north-seeking down, but become south-seeking at the 100 oersted demagnetization step and have little appreciable movement in direction of magnetization from 200 to 500 oersteds.

Site EB 101 is a northwest-trending diabase dike and initially has its magnetization north-seeking down at the 100 to 300 oersted "cleaning" steps, as shown in Figure 3b. At higher fields (400 oersteds and up), the magnetization becomes south-seeking.

Site EB104, a northwest-trending dike, is of a mixed polarity and has two discretely different directions of magnetization. Both remain quite consistent up to the maximum "cleaning" leve1 of 1000 oersteds. This is shown in Figure $3 c$.

Fina11y, site EB202, a northwest-trending dike, has an initial mixed magnetization, the south-seeking component of which becomes weak and disappears at AC partial demagnetization fields above 400 oersteds. The north-seeking component is still present at the 700 oersted leve 1 (fig. 3d).

Unlike the north-seeking down direction of magnetization, which appears to be related to dike trends having different ages, the southseeking component seems unrelated to either rock type, dike orientation, or age difference as it occurs in both the older granite and gneiss and in the younger diabase rocks, as we 11 as in dikes of different trends. Plotted directions for the south-seeking magnetization are shown in

Figure 4. 

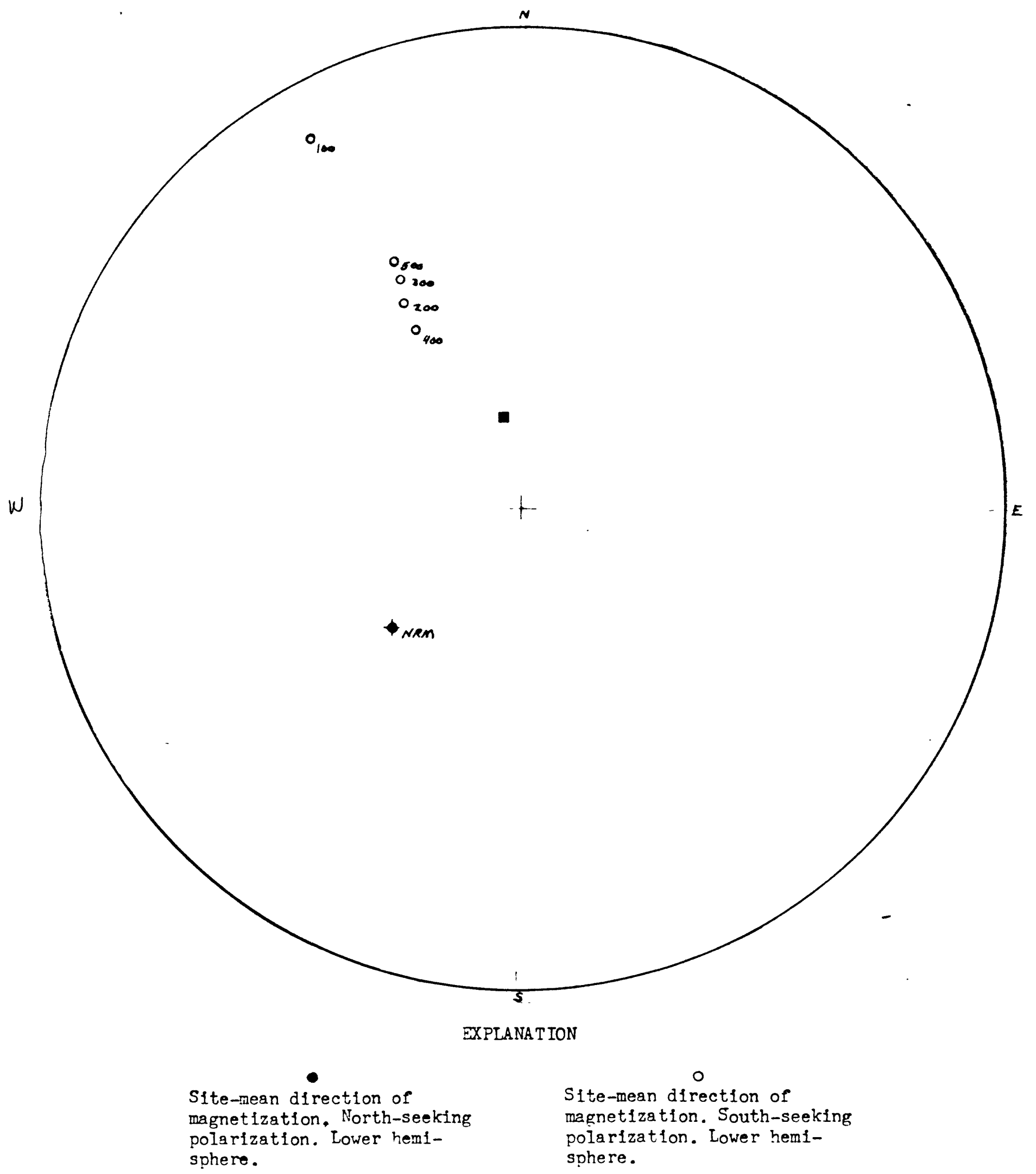

$\circ$

Site-mean direction of magnetization. South-seeking polarization. Lower hemisphere.

Figure 3a.--Site-mean directions of magnetization for A.C. (alternating current) partial demagnetization steps of Site EB2. NRM is the direction of natural remanent magnetization. 


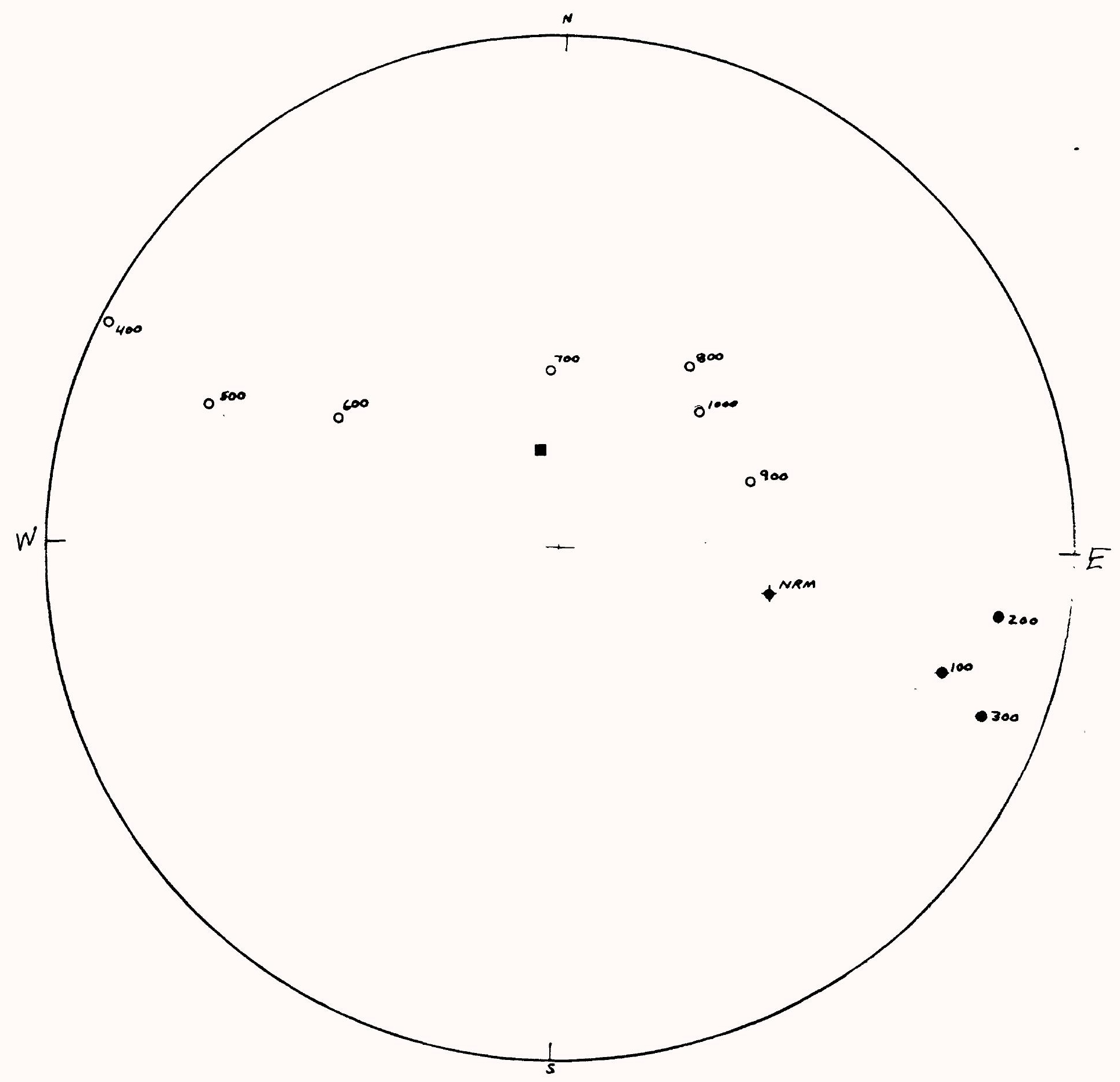

EXPLANATION

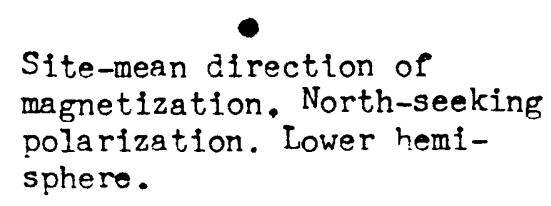

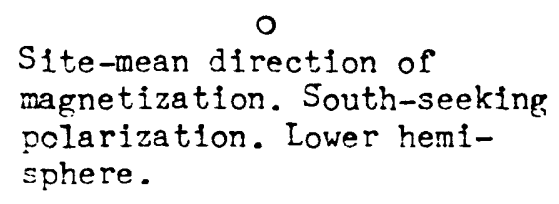

Site-mean direction of magnetization. South-seeking sphere.

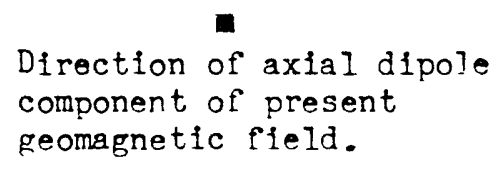

Figure 3b.--Site-mean directions of magnetization for A.C. (alternating current) partial demagnetization steps of Site EBl0l. NRM is the direction of natural remanent magnetization. 


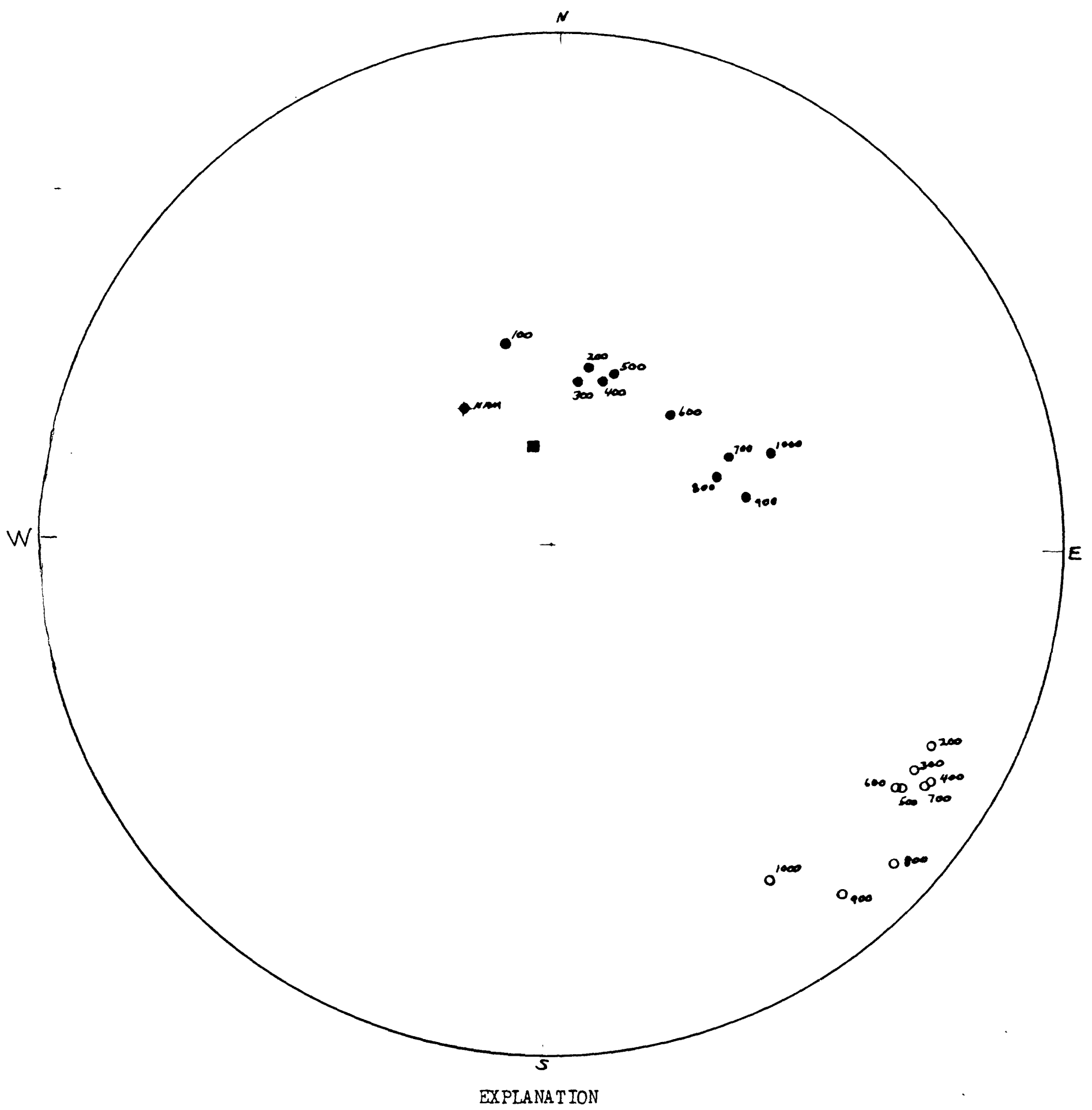

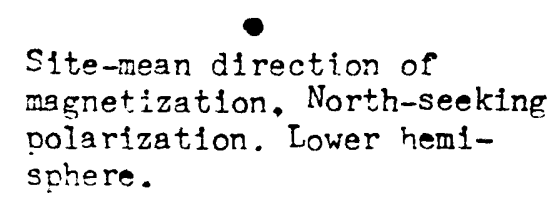

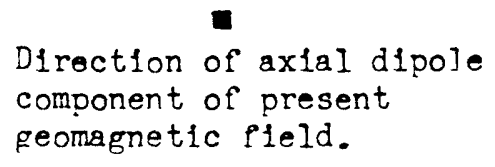

Figure 3c.--Site-mean directions of magnetization for A.C. (alternating current) partial demagnetization steps of Site EB104. NRM is direction of natural remanent magnetization. 

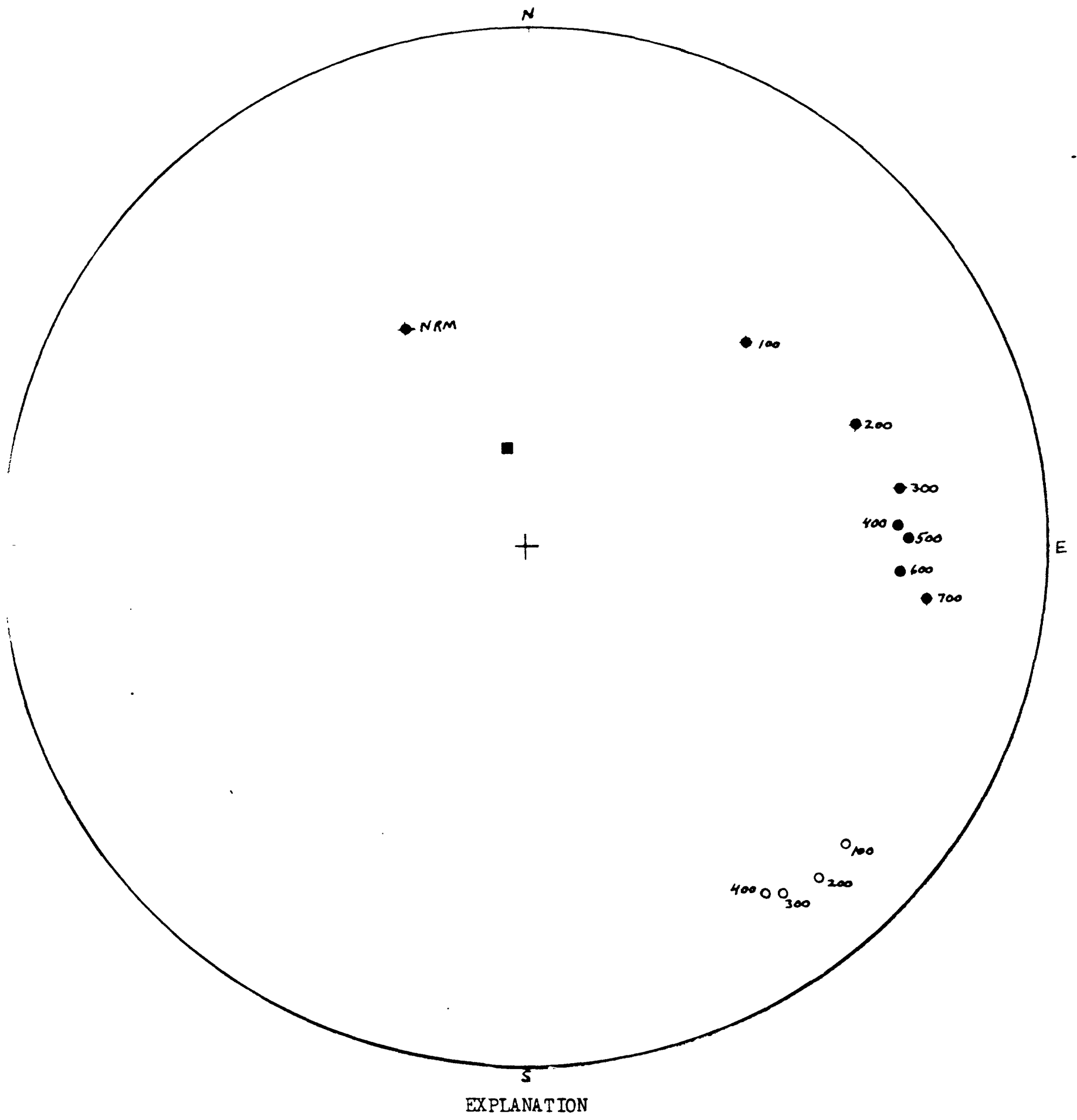

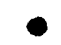

Site-mean direction of magnetization. North-seeking polarization. Lower hemisphere.
0

Site-mean direction of magnetization. South-zeeking polarization. Lower hemisphere.

Direction of axial dipole component of present geomagnetic field.

Figure 3d.--Site-mean directions of magnetization for A.C. (alternating current) partial demagnetization steps of Site EB202. NRM is direction of natural remanent magnetization. 


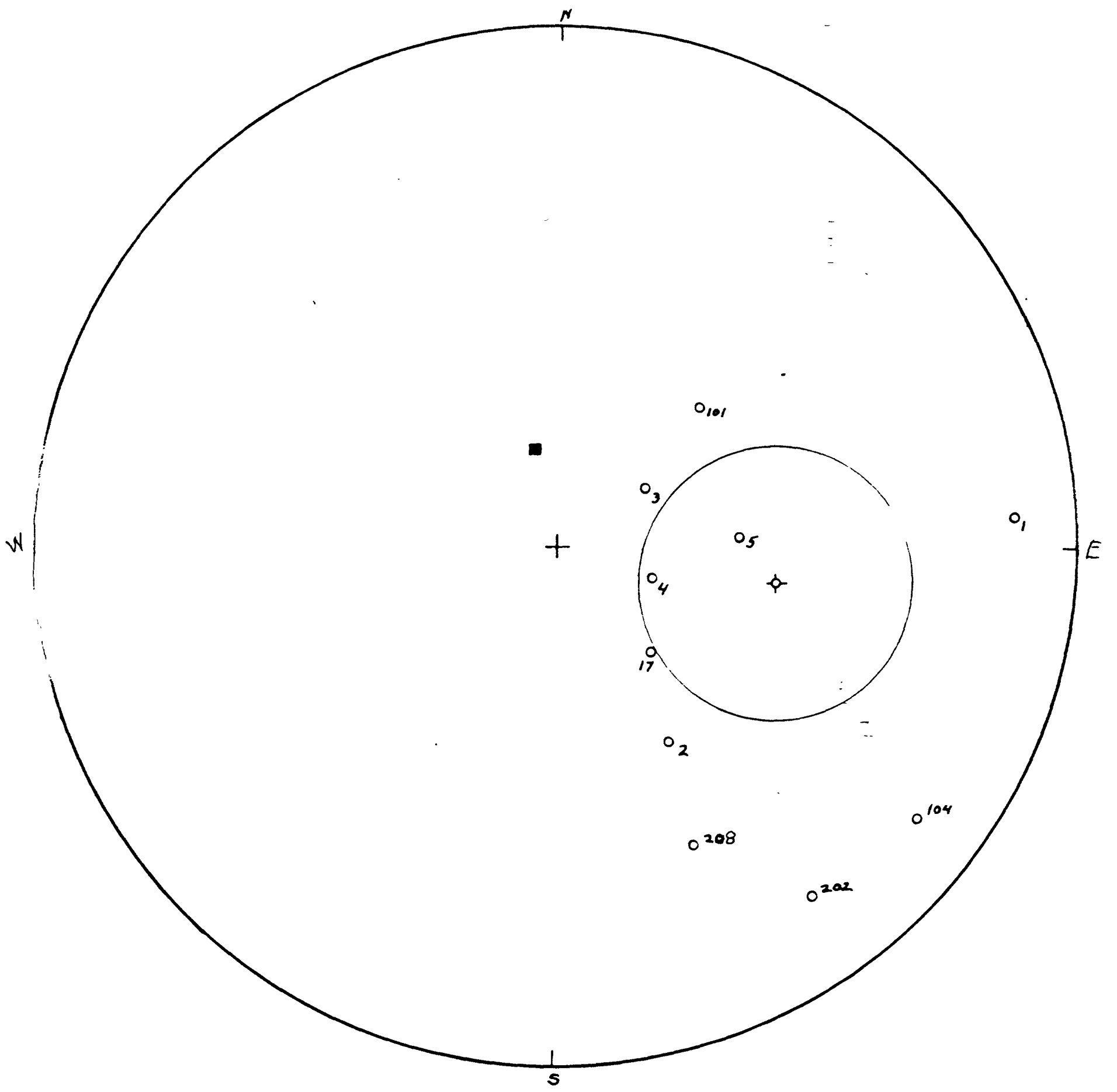

EXPLANATION

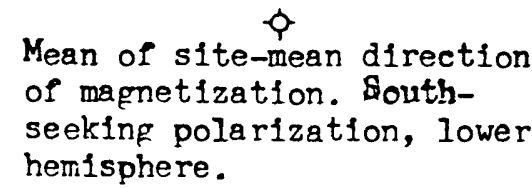

Mean of site-mean direction seeking polarization, lower hemisphere.

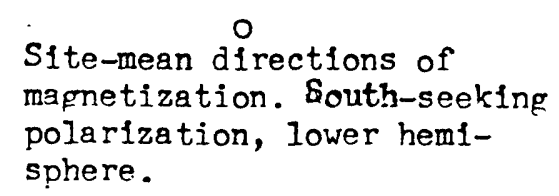

Direction of axial dipole

component of present

geomagnetic fleld.

Figure 4.--Mean of site-mean directions of magnetization for the south-seeking component of magnetization at the various sites. 


\section{Conclusions}

Because of a wide variation in results, the data from the rocks of this investigation probably do not warrant firm conclusions. However, the northwest- and northeast-trending dikes do have significantly different directions of magnetization for the north-seeking component. Because differently trending dikes (northeast and northwest) have different ages, as indicated by radiometric data, it would suggest the north-seeking polarity, by virtue of different direction of magnetization, is the more stable or original direction of magnetization in the area rocks. It is also significant that half of the sample sites have a south-seeking component of magnetization that is present in some degree in the oldest to the youngest rocks. Although scattered, the directions do show a general similarity for all sites and may indicate a later or secondary component of magnetization that is younger than the youngest dike rocks. 1 I

1/The diabase dikes are obviously much younger than the Grenville metasediments that show a $1 \mathrm{~b} . \mathrm{y}$. age of metamorphism. The south-seeking component occurring in both the metasediments and dikes suggests a late wide-spread thermal event affecting the entire region. Only two mineralization events are known here that are younger than the diabase dikes. These are mineralization phases 3 and 4 described by me (Brown, 1982; and Brown, in press). Phase 3 produced oxidation of iron-bearing minerals and hydrothermal alteration close to the Precambrian-Paleozoic unconformity. The iron deposits typified by those mined at Antwerp, N.Y., in the $1800^{\prime}$ 's are a result. Ore minerals are hematite and minor amounts of magnetic minerals such as maghemite and magnetite. This phase also produced barite and a wide range of secondary minerals where the preexisting Balmat zinc deposits were affected by it. Phase 4 produced the vertical galena-bearing veins previously mined near Rossie and Macomb, N.Y. This type vein is composed mainly of calcite with galena, sphalerite and fluorite. Similar calcite and sulfide veins are in rocks as young as Middle Ordovician in Ontario. Some hydrothermal alteration along joints in gneisses that locally produced epidote, reddened feldspar and quartz is also believed by me to be related to this mineralization stage.

The south-seeking component, prevalent in many of the samples, if it represents a regional magnetic feature, could explain the large regional negative magnetic anomalies in the Grenville lowlands shown on the aeromagnetic maps of the region (U.S. Geological Survey, 1975; Isachsen and others, 1979). C.E.B. 


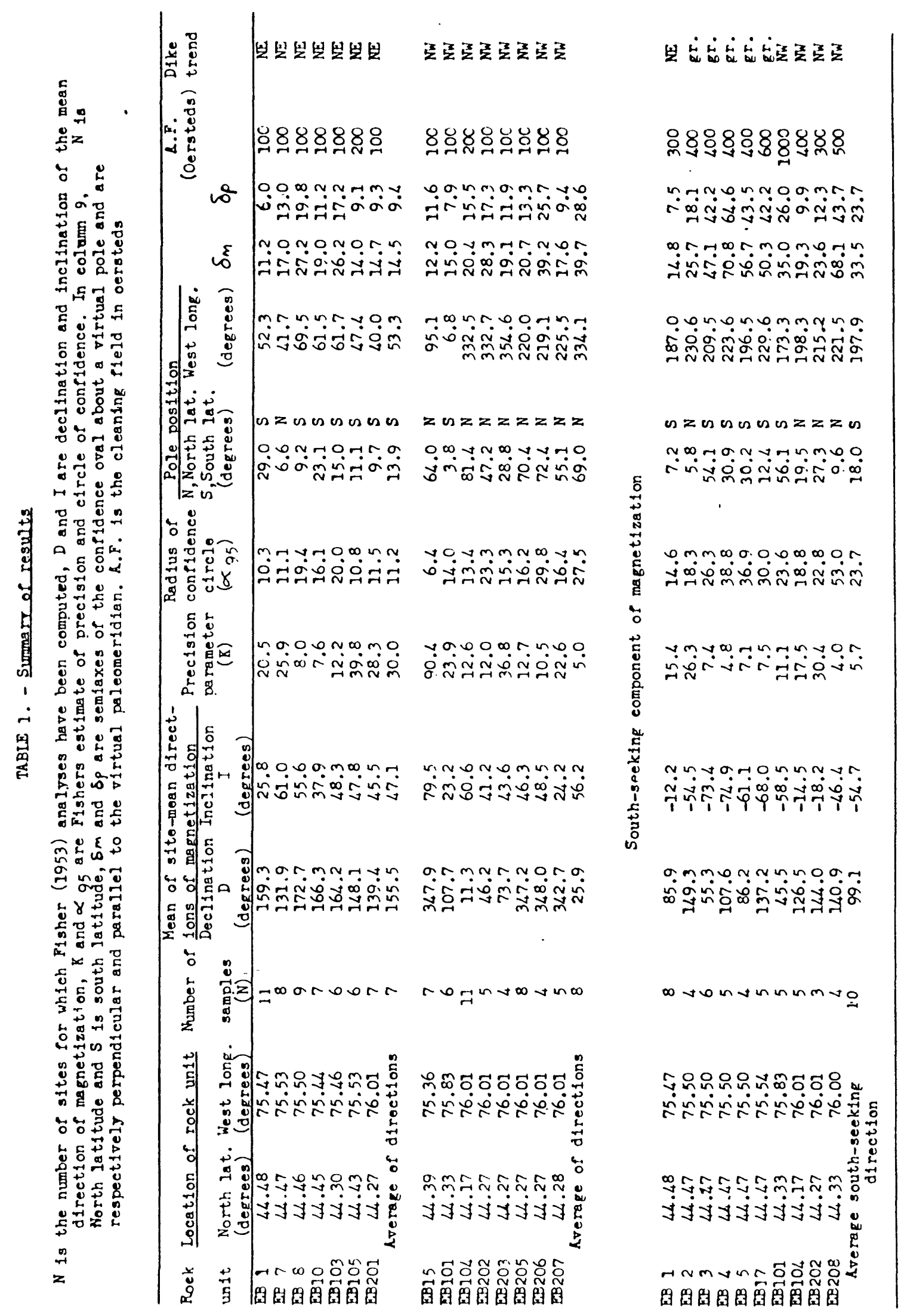


Table 2.--pike and lucation daca al bample sites (CEB).

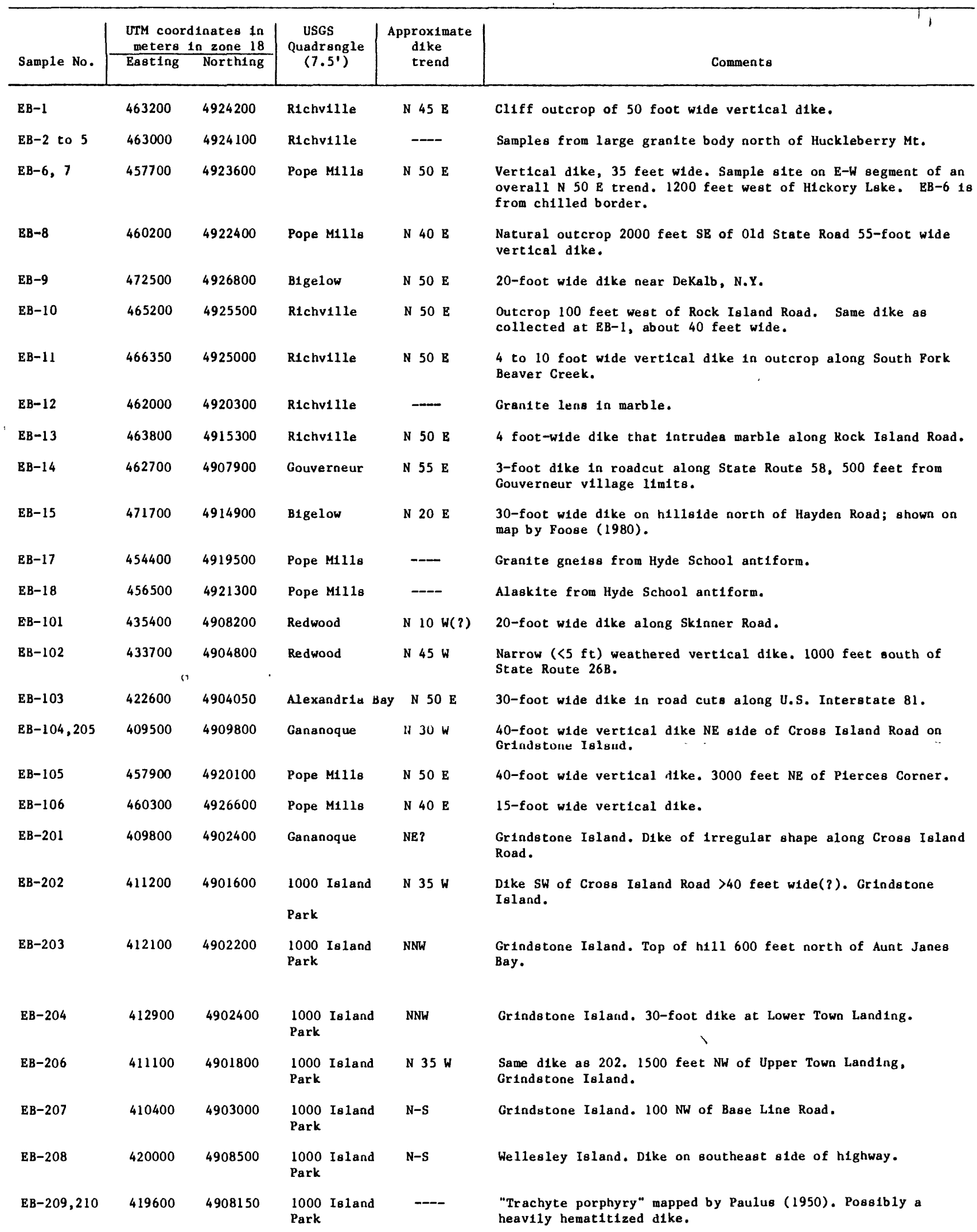




\section{References Cited}

Brown, C. Ervin, 1975, Problematical age of an alkaline analcite-bearing olivine diabase dike in St. Lawrence County, New York [abs.]: Geol. Soc. America Abstracts with Programs, v. 7, no. 1, p. 31.

Brown, C. Ervin, 1982, Mineralization in Proterozoic Y rocks of the St. Lawrence lowlands, New York, p. 12, in Geological Survey Research 1981: U.S. Geo1. Survey Prof. Paper 1275, 402 p.

Brown, C. Ervin, in press, Mineralization, mining, and mineral resources in the Beaver Creek area of the Grenville Lowlands in St. Lawrence County, New York: U.S. Geol. Survey Prof. Paper 1279.

Buddington, A. F., 1929, Granite phacoliths and their contact zones in the northwestern Adirondacks: New York State Mus. and Sci. Srevice Bu11. 281, p. 51-107.

Car1, J. D., and Van Diver, B. B., 1975, Precambrian Grenville alaskite bodies as ash-flow tuffs, northwest Adirondacks, New York: Geol. Soc. America Bu11., v. 86, p. 1691-1707.

Cushing, H. P., Fairchild, H. L., Ruedemann, R., and Smyth, C. H., Jr., 1910, Geology of the Thousand Islands Region: New York State Mus. and Sci. Service Bu11. 145, 194 p.

Fahrig, W. F., Irving, E., and Jackson, G. D., 1971, Paleomagnetism of the Franklin diabases: Canadian Jour. Earth Sci., v. 8, p. 455-467.

Fisher, R. A., 1953, Dispersion on a sphere: Royal Soc. London Proc., v. 217 , p. 295-305.

Foose, M. P., 1980, Map showing geology and structure of the Bigelow area, northwest Adirondocks, New York: U.S. Geol. Survey, Misc. Field Studies Map MF-1187.

Isachsen, Y. W., Brown, C. E., Zietz, I., 1979, Preliminary interpretation of an aeromagnetic map of most of the Adirondack Mountains and Upper St. Lawrence Valley, New York: Geol. Soc. America Abstracts with Programs, v. 11, no. 1, p. 17.

Park, J. K., and Irving, E., 1972, Magnetism of dikes of the Frontenac axis: Canadian Jour. Earth Sci., v. 9, p. 763-765.

Paulus, F. J., 1950, Geology of the Grindstone Quadrangle, Jefferson County, New York: MS Thesis, University of Rochester, Rochester, New York. 
Pesonen, L. J. and Halls, H. C., 1979, The paleomagnetism of Keweenawan dikes from Baraga and Marquette Counties, northern Michigan:

Canadian Jour. Earth Sci., v. 16, no. 11, p. 2136-2179.

Smyth, C. H., Jr., 1894, A group of diabase dikes among the Thousand Islands, St. Lawrence River, New York: Am. Jour. Sci., 5th ser., v. 22, p. 71-80.

U.S. Geological Survey, 1975, Aeromagnetic Survey of the Ogdensburg, New York, area: U.S. Geo1. Survey Open-File Report 75-526. 